\title{
Identity-oriented English Language Teachers' Education Programs as the Arena of Becoming a Glocal English Language Teacher
}

\author{
Hussein Meihami
}

Shiraz University, (P.O. Box 71964-84334), Eram Square, Shiraz, Iran, hussein.meihami@yahoo.com

\begin{abstract}
The purpose of the current study is to investigate the potentials of identity-oriented English language teachers' education programs in developing the glocal identity of English language teachers through examining the perspectives of the EFL teacher educators. Given that, the main features of glocal identity teacher education program were obtained by examining their perspectives. These features are addressing reflective pedagogy, bridging the gap between theory and practice, involving English language teachers in action research, and developing English language teachers' critical thinking skills in teacher's education programs.
\end{abstract}

Keywords: glocal education, identity-oriented, action research, reflective practice.

\section{Introduction}

Teacher's identity development has been considered as an important issue in teacher's professional development. The reason may be related to the point that understanding teacher's identity (Gergen, 1991) and preparing education programs for developing teacher's identity can develop overall teacher's professionalism (Irwin and Hramiak, 2010). Due to the complex nature of teacher's identity development (Pupala, Kascak and Tesar, 2016), the realm of teacher's identity research has witnessed a flourishing development in doing research by scholars (Meihami and Salite, 2019; Rashidi and Meihami, 2017). Moreover, different movements in educational settings of different countries and the relationships existing between the local and global educational contexts (Skerritt, 2018) make the educational researchers exercise more emphasis on the teacher's identity 
development research. Furthermore, because of the identity is not a fixed attribute of human being (Rashidi and Meihami, 2019; Vargehese, Morgan, Johnston and Johnson, 2005), the change in the educational contexts will lead to its change, which in its own way is a reason for the keen enthusiasm of the researchers in doing teacher's identity development research.

The identity is a multifaceted construct (Bilgen and Richards, 2015), it is necessary to consider its different dimensions and to provide a comprehensive definition for it. Norton (2013) describes identity as a part of an individual, which helps the individual to understand and constructs his/her relationships with "others" in a step-wise manner and to create new possibilities in his/her life. In like manner, Preece (2016) points out that identity is a socially constructed phenomenon which is created by the interactions existing among "self" and "others", as the "result of the mobility and diversity that has arisen in the social worlds of the physical and digital world due to the processes of globalisation in late modernity" $(2016,3)$. What is implicitly addressed in these two definitions is "negotiating self"; meaning that the interactions among the individuals of a community will provide a venue for negotiating their beliefs, attitudes, values, assumptions, etc. (Heller, 1987). In this way, the individuals have a constant influence on the members of their community and, at the same time, they are influenced by them. However, when reviewing the research studies on English language teacher's identity development (e.g., Trent, 2010; Yuan and Burn, 2017), one can perceive that it is not easy for these teachers to negotiate their identity, because of the struggles such as teachers' different understandings of the environmental issues, their professional engagements, and the way they try to establish a relationship between their current identity with the one they want to adopt in future (Edwards and Burns, 2016).

Being, doing and becoming an English language teacher is directly related to the teacher's identity development. It is like a process, in which the current status of a teacher and his/her beliefs, values, and assumptions are considered as the "being" of a teacher. Teachers are busy doing practices during their teaching profession, which impose new identity in them. When the imposed identity through the new practices is established as a part of the teacher's identity, the teacher is said to become a teacher with the identity, which has the characteristics of the already done practices. This process is critical not only in English language teacher's identity development, but also it is important in the identity development of the teachers of any other disciplines. The process of being, doing and becoming a teacher, the educational policy makers can understand the process of educating competent teachers in different respects. Furthermore, if the teachers themselves will be able to understand this process, they will be able to participate in negotiating their identity in a dialogic way (Bakhtin, 1990), in which a balanced identity development can be resulted. If English language teacher educators prepare a teacher's education program in that, the English language teachers can act upon their identity in the process of being, doing, and becoming, the results can be successful teachers in the 
act of English language teaching. However, it is highly important to note, that since the English language has got a role as the international language for the communication of people all around the world, and due to the various varieties of the local characteristics of the people, who want to learn English, it will not be an easy task to prepare an identity-oriented English language teacher's education program.

\section{Purpose of the study}

The research question - why is it important to have an identity-oriented English language teacher's education program to educate glocal English language teachers? The first reason is that, since the final objective of English language teaching has been declared to empower the learners to communicate cultural meanings appropriately (Rashidi and Meihami, 2016; Rodríguez and Espinar, 2015), and since the cultural meanings are not fixed and making decisions on as an appropriate one is not easy, the English language teachers become confused regarding how to address the cultural issues in their classrooms. Such a situation is also true when the political and social phenomena happen to be discussed in the English language classrooms. The English teachers are, more often than not, have problems how to handle and deal with such discussions. When adding to this reason the global aspects, such as discussing global political issues in the classroom, the situation will be even more harsher for the English teachers to deal with. That is said, if an identity-oriented English teacher's education program, whose concern is the glocal identity development of the English language teachers will be run, then, the English language teachers will find a venue how to react regarding these issues, in which they may accept a glocal identity in these programs; meaning that the identity-oriented program will have a pedagogical implication for the teachers. Moreover, by participating in such programs, the English language teachers will be familiar with the discourse of identity negotiating. It will, then, contribute them to participate in identity constructing practices, which can help in removing the problems that have already mentioned above. Hence, the purpose of the current study is to address the main features, which are necessary to run an identity-oriented English language teacher's education program, which has the focus on developing the glocal identity of the English language teachers. To sum up, the current study is an attempt to address the requirements of such a program based on a critical discussion on the contexts of English language teaching and learning, by doing an investigation of EFL teachers educators and EFL teachers perspectives of having an identity-oriented EFL teacher's education programs, which construct the glocal identity of EFL instructors.

\section{English language teaching and learning: A cosmopolitan act}

The current status of English language as an international language has significantly contributed to the dissemination of the values, beliefs, thoughts, assumptions, etc. of the people around the world (Shen, Eslami and Chen, 2011). Through using English 
language, people of different cultural and ethical backgrounds will be able to negotiate their identity, as well as, their authority in the globalised world. It is why Stanton (2006) considers English language teaching as a "cosmopolitan act", because in the globalisation time, in which the boundaries are omitted, English language teaching provides a unique venue for negotiating cultural, ethical, political and social concepts among the people of different communities. However, there should be a balance between the local and global identity negotiation, so that the stockholders of English language teaching and learning, including teachers and learners, will be able to participate in negotiating their identity. By so doing, the impact of hidden curricula as the "unstated norms, values, and beliefs that are transmitted to students [or even teachers] through the underlying structure of a given class" (Giroux, 1988, 51), will be adjusted, in which the context of teaching and learning English language will be a fair venue of negotiating identities. Here, it is believable, that the English teachers should carry more burden to prepare a context of identity negotiation, in which the local and global identity related issues, will be considered and addressed. It can be assumed, that the policy makers should think of an identity-oriented English language teacher's education program to prepare English language teachers for acting in the glocal context.

The notion of glocal refers "to see the local in the global and the global in the local" (Trippestad, 2016, 20); meaning that one should concern both local and global issues and be able to step in a space, both are equally addressed. The teacher's education program, which the main purpose is to educate a glocal teacher, should follow a vision, in which the teachers are respected for their local attributes and are acknowledged for their history and culture; moreover, simultaneously, "a common universal understanding, interconnectedness and humanistic potential of globalisation” (Trippestad, 2016, 20) is taken into account. The glocal education, then, has two spaces with some lines of overlapping in between: on the local part, it is related to what education traditionally wants to develop in individuals, such as autonomy, critical thinking, and self-decision (Løvlie, 2009) based on the opportunities existing in local culture and society. It is in this phase of glocal education which the individuals will be able to probe into their identity and investigate different aspects of their "self-image". Furthermore, we are living in a globalised world, in which we are considered as world citizens. This means that individuals need to have different competences, such as intercultural communication competency, in order to be able to come up with the universal trends. This is the second phase of glocal education, in which individuals are provided with the notions and concepts to be competent for global life. In between, the overlapping space; moreover, the individuals participating in glocal education will learn how to negotiate their own self in a global context with others' self.

Based on what has been said, a glocal teacher needs to be able to preserve the differences in case of local culture, history, and traditions in a global age. As Trippestad (2016, 22) asserts that "glocal teacher ... must teach the students the personal and the local, the polis and the common culture, and the global and the universal, to create a harmonious 
and balanced education." This is implying that the glocal teachers should be competent enough to help their students participate in a meaning making process, in which the local and global meanings are addressed to empower the students to make use of their critical thinking skills, as well as other skills such as problem solving ones to create their own global identity out of their local identity and vice versa. Such teachers will be rhetorically agent; meaning that they can have different impacts on others. Overall, this means that a glocal teacher has an identity leading him/her to develop the identity of his/her students based on the local assets and global requirements.

Thinking of glocal English language teachers needs to prepare an identity-oriented English language teacher's education in order to enhance the glocal identity in English language teachers. More often than not, English language teachers are not native speakers of English, but they are non-native speakers, who are involving in teaching English in different countries. Given that, English is no more the language of native speakers and this is the emergent of English world (Canagarajah, 2007), based on which defining standard English is no more the concern of English language teaching and learning. Moreover, not all English teachers instruct English as a second language (ESL), but many of them are involving teaching English as a foreign language (EFL). While in the former, ESL context, English language is the dominant language, in that the learners are from different cultural and social background, and their communication is done through the medium of English language, in the latter one, EFL context, English is not the dominant language and the learners, mostly, share similar first language and cultural backgrounds. The two contexts require different educational supports on the part of the teachers to teach English language to their teachers. Related to this issue there are differences in the political and social status of the contexts, in which English is instructed. These reasons are a few from a more number of issues, which show the crucial importance of English language teacher's education programs, in order to develop English teaching profession in different contexts.

\section{Methodology}

\section{Participants}

This study was a part of a larger qualitative study conducted by Meihami (2019), in which the researcher (Meihami, 2019) aimed to obtain the perspectives of English language teacher educators and English teachers to reach commonality about the features of identity-oriented English language teacher's education programs. The participants of the study were three EFL teachers-educators and five EFL teachers with a different range of year-of-teaching experiences. The three EFL teachers-educators hold Ph.D. in applied linguistics and taught Teaching English as a Foreign Language (TEFL) at B.A., M.A., and Ph.D. levels. The EFL teacher educators' year-of-teaching experiences ranged from seven 
to fifteen years. Moreover, five EFL teachers participated in this study. Four of them were Ph.D. candidates in applied linguistics (all male), and one of them was an M.A. graduated student in applied linguistics (the female one). Their year-of-teaching experiences ranged from three to seven years. Through the course of data collection for the study, the researcher of the current study asked the participants who have already participated in the study conducted by Meihami (2019) to participate in a series of semi-structured phenomenological interviews to obtain information for the purpose of the current study. In the following section, data collection and data analysis have been explained.

\section{Data collection and data analysis}

To address the aim of this study, which was - to obtain the main features of identity-oriented EFL teacher's education program, which can help to the construction of the glocal identity of the EFL teachers, a series of semi-structured phenomenological interviews were run. According to Ary, Jacobs, Sorenson, and Walker (2014) phenomenological interview helps to obtain the main perspectives of the interviewees about an issue. Ary et al. (2014) stated, that there are three phases which should be followed when conducting a phenomenological interview: investigating the past experiences and practices; examining the current issues; and the connection between past experiences and practices and the current issues. The researcher did his best to follow these phases when conducting the interviews.

After conducting the interviews, the researcher followed the systemic approach proposed by Strauss and Corbin (1998) to obtain the main themes of the analysed interviews. To do so, the researcher needed to address the interviews based on three levels of coding: open coding, axial coding, and selective coding.

Table 1

Analysis of the Interviews Based on Systemic Approach (Extracted from Meihami 2019)

\begin{tabular}{|c|c|c|c|}
\hline (English language teacher educator) & $\begin{array}{l}\text { Open } \\
\text { Coding }\end{array}$ & $\begin{array}{c}\text { Axial } \\
\text { Coding }\end{array}$ & $\begin{array}{r}\text { Selective } \\
\text { Coding }\end{array}$ \\
\hline $\begin{array}{l}\text {... teacher trainers should also enable } \\
\text { teachers to make spontaneous deci- } \\
\text { sions about material selection, tech- } \\
\text { niques, and methods geared towards } \\
\text { learners at different contexts ... }\end{array}$ & $\begin{array}{l}\text { Identity development } \\
\text { Reflective Pedagogy }\end{array}$ & $\begin{array}{l}\text { Professional } \\
\text { identity }\end{array}$ & $\begin{array}{l}\text { Reflective } \\
\text { teaching } \\
\text { Action } \\
\text { research }\end{array}$ \\
\hline
\end{tabular}

Open coding helps the researcher to obtain the main categories; axial coding is helpful to convert the main categories to sub-categories. Finally, through selective coding, the researcher develops propositions and hypotheses. Below is an example extracted from Meihami (2019). 
As it can be seen through Strauss and Corbin's (1998) systematic approach, the researcher reached a theme called reflective teaching to address glocal identity of the EFL teachers. It should be stated, that through conducting meticulous systematic approach, the main themes were obtained including addressing reflective pedagogy, bridging the gap between theory and practice, involving English language teachers in action research, and developing English language teachers' critical thinking skills in teacher's education programs which are discussed below.

\section{Results and discussion}

In this section, the features of the identity-oriented English language teacher's education programs, which contribute to the construction of glocal identity in the EFL teachers, will be discussed. Moreover, there will be an attempt to discuss how the glocal identity of the English language teachers can be developed through participating in these education programs. After analysing the interviews, the researcher reached four main features, which should be involved in the EFL teacher's education programs, in order to help EFL teachers construct their glocal identity. These features are addressing reflective pedagogy, bridging the gap between theory and practice, involving English language teachers in action research, and developing English language teacher critical thinking skills.

\section{Involving glocal English language teacher in reflective pedagogy}

Reflective pedagogy is described by Beck $(2019,95)$ as "a teaching approach that is dialogical, critical, inquiry-oriented, and inclusive." Through examining the key notions asserted by Beck (2019), one can state that the reflective pedagogy includes a co-constructed of critical meanings. This will lead to co-construction of identity through negotiation. Doing reflection in the classroom will help the English language teachers to reflect on new practices, which provide new identity for them. Different types of reflection help the English language teachers to evaluate their own practices in the classrooms and develop their classroom practices based on activities such as critical friends and collaboration (Beck and Kosnik, 2014).

The glocal English language teachers need to reflect upon the global and local aspects of the practices, which they are doing in their classrooms. Given that, the identity-oriented English language teacher's education programs should be a place, in which the English language teachers will be able to practice reflection on the global and local aspects of English language teaching. If goes in this way, the English language teachers can establish a rhetorical agency, which is the ability to influence others and to develop the capacity of accepting the influence of others (Trippestad, 2016). Hence, identity-oriented English language teacher's education programs should develop the reflection competency of the English language teachers with regard to the rhetorical agency including language, 
communicative practices, and traditions. As a whole, it can be assumed that by helping the English language teachers to develop the reflection practice ability during the identity-oriented English language teacher's education programs, they will be able to exercise more on the glocal practices, which can develop their glocal identity.

\section{Familiarizing glocal English language teacher with theory and practice}

There is a long-lasting discussion on the complexity of making a connection between theory and practice, not only in second language teaching and learning, but also in almost all professions (Kvernbekk, 2012; Zand-Moghadam and Meihami, 2016). Ulvik and Smith (2019) believe, that English language teachers expect the English language teacher's education programs as a venue, which is showing the relevance of theory and practice to them. Providing a bridge between theory and practice is difficult to address, because of the reality of instructional context. Given that, it is assumed that if the English language teacher's education programs will provide an abstract knowledge of the theories, the English language teachers will be able to practice them in different contexts.

When concerning the glocal identity development of English language teachers through identity-oriented English language teacher's education programs, it is highly important to provide contexts for the English language teachers, in which they will be able to participate and act in different education discourses. The identity-oriented English language teacher's education should address "a meta-perspective on education as a vital component in pre-service teacher's education to be followed up in further professional development" (Ulvik and Smith, 2019, 132); it means, that educated teacher is having a global understanding of the theories so that they will able to apply them in different contexts. Providing the English language teachers with glocal identity needs to take into account the overall vision of theory and practice, regarding local and global contexts. For instance, the English language teachers should know how to address the local issues, while they are preparing their students for global communication.

\section{Glocal English language teacher as an action researcher}

Action research which is, often, considered the same as reflective practice is a venue for the teachers to change the "self" (Goodnough, 2010). However, it is highly important to note, that there is a difference between action research and reflective practice, which aware the researchers not to consider them identical. According to what McMahan (1999) asserts, there is a strategic action notion in action research, which is not the case for the reflective practice. This strategic action requires the action researchers to follow a meticulous, coherent, reliable methodology to solve an issue. According to Borg (2017) the teachers, who are involving in doing action research are in a constant process of identity construction. By accepting a teacher's- researcher's identity, the teachers will be able to investigate new possibilities which they encounter in a different community of practices (Wenger, 1998), which they have already joined. Moreover, becoming and acting as 
teacher-researchers, who do action research will help the teachers to accept and participate in other identities, such as being decision makers, syllabus designers, or consultants.

One of the prerequisites to develop the glocal identity in the English language teachers is to engage them in doing action research. By referring to the definition of glocal education, one can perceive that the teachers, who involve in glocal education contexts are always in a critical point that they should go through local and global concepts and to make appropriate decisions about them. Now, by considering the English language teaching and learning and its features, it can be stated. that the English language teachers are in a constant decision making stance with regard to the phenomena, which happen in their classroom. For instance, there are some unanswered questions for the English language teachers such as whose culture (L1, L2, international) should be addressed, which syllabus (local or global) should be followed, which kind materials (locally designed or globally designed) should be used and instructed, etc. That is said, the English language teachers can do action research to decide on strategic actions to deal with such questions. The identity-oriented English language teacher's education can help the English language teachers to develop their identity as teachers-researchers with a glocal orientation; meaning that conducting research in relation to glocal issues in English language teaching and learning contexts. To do so, the identity-oriented English language teacher's education program can involve English language teachers in a process-based instruction of doing research.

\section{Developing glocal English language teacher's critical thinking skills}

It is always stated that the ultimate goal of education is to help individuals to acquire thinking skills. This is a context-based issue, which means that different situations require different thinking skills. Hence, critical thinking skills can help "to identify questions worth pursuing, being able to pursue one's questions through self-directed search and interrogation of knowledge, a sense that knowledge is contestable and being able to present evidence to support one's arguments" (Pithers and Soden, 2000, 238). Teachers need to acquire critical thinking skills, in orderto cope with differences in the classrooms. That is said, if the teachers have critical thinking skills, they will be able to participate in different discourses (Lo'pez-Facal and Jime'nez-Aleixandre, 2009).

The glocal English language teachers are involved in different discourses, which ask them to make decisions. Hence, they should possess critical thinking skills, in order to be able to participate in locally and globally related discourses. According to Meihami (2019), English language teachers' critical thinking skills can be developed through their participating in negotiation about different issues, associated with English language teaching contexts. Consequently, the identity-oriented English language teacher's education programs should provide a place, in which the English language teachers can negotiate about different issues including the glocal issues. The potentiality of negotiation in developing English language teachers' glocal identity may lie in its definition 
which is "one of the possible means of "getting things accomplished" (Strauss, 1978, 11). Consequently, when individuals, including English language teachers, participate in negotiation sessions, they will involve in discussions requiring their critical thinking skills. Sequentially, if identity-oriented English language teacher's education programs problematise the glocal varieties in the English language teaching and learning contexts and ask the English language teachers to negotiate them, the results can be developed in critical thinking skills of these teachers, which in its own place help to glocal identity development of them.

\section{Conclusion}

It is now clear, that the current status of English as an international language ask for thinking about including glocal education concepts in English language teaching and learning contexts. Consequently, it will be the responsibility of language pedagogy policy makers to plan English language teacher's education programs in a way, that they can develop the glocal identity of the English language teachers. By so doing, the English language teachers will be able to build upon respect for the individual and the local, with an understanding and respect of the history, political and cultural institution of a country or state, while, at the same time, realising a common universal understanding, interconnectedness and humanistic potential of globalisation. All these are necessary in an international corporation of education (Trippestad, 2016, 20).

When considering the context of teaching English as a second or foreign language with all those diversities existing in local and global aspects regarding this language, the unquestionable need to an identity-oriented English language teacher's education program to develop the glocal identity of these teachers is well-acknowledged. The shift from local and global teaching discourses to the glocal one highlights more the need for an identity oriented English language teacher's education, now, and in the future.

Accordingly, the policy-makers need to prepare such programs with having in mind the features, which help to develop the glocal identity of English language teachers, encompassing addressing reflective pedagogy, bridging the gap between theory and practice, involving English language teachers in action research, and developing their critical thinking skills. If these features will be focused through negotiation in identity-oriented English language teacher's education programs, the glocal identity can be developed in English language teachers. It is highly suggested, that the policy- makers in language teacher's education think of these features for their future teacher's education program instead of solely focus on providing banking education to the teachers. 


\section{Declaration of conflicting interests}

The author declared no potential conflicts of interest with respect to the research, authorship, and/or publication of this article.

\section{Funding}

This research received no specific grant from any funding agency in the public, commercial or not-for-profit sectors.

\section{References}

Are Trippestad, T. (2015). The glocal teacher: The paradox agency of teaching in a glocalised world. Policy Futures in Education, 14(1), 9-23.

Ary, D., Jacobs, L.C., Sorensen, C. K. and Walker, D. (2014). Introduction to Research in Education. (9th Ed).

Bakhtin, M. M. (1990). Art and answerability: Early Philosophical Essays. Michael Holquist (Ed.), Vadim Liapunov (Translator), Kenneth Brostrom (Translator). Texas: University of Texas Press.

Beck, C. (2019). Learning to Walk Your Talk: The Pre-service Campus Programme as a Context for Researching and Modelling Reflective Pedagogy in an Era of Transmission and Testing. In J. Murray, A. Swennen \& C. Kosnik (eds.). International Research, Policy and Practice in Teacher Education (pp. 93-105). Springer, Cham.

Beck, C., and Kosnik, C. (2014). Growing as a Teacher: Goals and Pathways of Ongoing Teacher Learning. Rotterdam: Sense Publishers.

Bilgen, F. E. and Richards, K. (2014). Identity Negotiations of TEFL Teachers During a Time of Uncertainty and Redundancy. In YL Cheung, S. B., Said, \& K. Park (Eds.). Advances and Current Trends in Language Teacher Identity Research (pp. 83-95). New York: Routledge.

Borg, S. (2017). Action Research and Teacher Identity. The 2016 Cambridge English/English UK Action Research Scheme, 2.

Canagarajah, S. (2007). Lingua franca English, Multilingual Communities, and Language Acquisition. The Modern Language Journal, 91(1), 923-939.

Edwards, E. and Burns, A. (2016). Language Teacher-researcher Identity Negotiation: An Ecological Perspective. TESOL Quarterly, 50(3), 735-745.

Gergen, K. J. (1991). The saturated Self: Dilemmas of Identity in Everyday Life. New York: Basic Books.

Giroux, H. A. (1988). Teachers as Intellectuals: Toward a Critical Pedagogy of Learning. Greenwood Publishing Group.

Goodnough, K. (2010). The Role of Action Research in Transforming Teacher Identity: Modes of Belonging and Ecological Perspectives. Educational Action Research, 18(2), 167-182. 
Heller, M. (1987). The Role of Language in the Formation of Ethnic Identity. In J. Phinney and M. Rotheram (Eds). Children's Ethnic Socialization (pp. 180-200). Newbury Park, CA: Sage. Irwin B and Hramiak A. (2010). A Discourse Analysis of Trainee Teacher Identity in Online Discussion Forums. Technology Pedagogy and Education, 19(3), 361-377.

Kvernbekk, T. (2012). Argumentation in Theory and Practice: Gap or Equilibrium? Informal logic, 32(3), 288-305.

López-Facal, R., and Jiménez-Aleixandre, M. P. (2009). Identities, Social Representations and Critical Thinking. Cultural Studies of Science Education, 4(3), 689-695.

Løvlie, L (2009). Dannelseogprofesjon. Oslo: Dannelsesutvalgets rapport april 2009.

McMahon, T. (1999). Is Reflective Practice Synonymous with Action Research? Educational action research, $7(1), 163-169$.

Meihami, H. (2019). The Role of Negotiation in Developing ESP and EGP Teachers' Cultural Identity. An Unpublished PhD Dissertation.

Meihami, H., \& Salite, I. (2019). EFL Teachers' Cultural Identity Development Through Participating in Cultural Negotiation: Probing EFL Students' Perspectives. Journal of Teacher Education for Sustainability, 21(1), 115-127.

Norton, B. (2013). Identity and Language Learning: Extending the Conversation. London: Multilingual matters.

Pithers, R. T. and Soden, R. (2000). Critical Thinking in Education: A Review. Educational Research, 42(3), 237-249.

Preece, S. (2016). The Routledge Handbook of Language and Identity. New York: Routledge.

Pupala, B., Kascak, O., and Tesar, M. (2016). Learning how to do up Buttons: Professionalism, Teacher Identity and Bureaucratic Subjectivities in Early Years Settings. Policy Futures in Education, 14(6), 655-665.

Rashidi, N., and Meihami, H. (2016). Hidden Curriculum: An Analysis of Cultural Content of the ELT Textbooks in Inner, Outer, and Expanding Circle Countries. Cogent Education, 3(1), 1-18. Rashidi, N., and Meihami, H. (2017). Addressing Cultural Identity Through Negotiation: Analysis of Student-teacher-authored Narratives. Journal of Teacher Education for Sustainability, 19(2), 21-35.

Rashidi, N., and Meihami, H. (2019). The Role of Negotiation about Cultural Issues on the ESP Teachers' Cultural Identity Development: A Narrative Inquiry. X Linguae, 12(2), 111-129.

Rodríguez, A. R. R., \& Espinar, A. A. (2015). General and Specific Culture Learning in EFL Textbooks Aimed at Adult Learners in Spain. Studia Anglica Posnaniensia, 50(1), 5-25.

Shin, J., Eslami, Z. R., and Chen, W. C. (2011). Presentation of Local and International Culture in Current International English-language Teaching Textbooks. Language, Culture and Curriculum, 24(3), 253-268.

Skerritt, C. (2018). Discourse and Teacher Identity in Business-like Education. Policy Futures in Education, 17(2), 153-171.

Stanton, D. C. (2006). Presidential Address 2005: On Rooted Cosmopolitanism. PMLA, 121(3), 627-640. 
Strauss, A. L. (1978). Negotiations: Varieties, Contexts, Processes, and Social order. San Francisco: Jossey-Bass.

Strauss, A., \& Corbin, J. (1998). Basics of Qualitative Research. Thousand Oaks. Wadsworth: London.

Trent, J. (2010). Teacher Education as Identity Construction: Insights from Action Research. Journal of Education for Teaching, 36(2), 153-168.

Ulvik, M., and Smith, K. (2019). Teaching about Teaching: Teacher Educators' and Student Teachers' Perspectives from Norway. In J. Murray, A. Swennen\& C. Kosnik (eds.). International Research, Policy and Practice in Teacher Education (pp. 123-137). Springer, Cham.

Varghese, M., Morgan, B., Johnston, B., and Johnson, K. A. (2005). Theorizing Language Teacher Identity: Three Perspectives and Beyond. Journal of language, Identity, and Education, 4(1), 21-44.

Wenger, E. (1998). Communities of Practice: Learning, Meaning, and Identity. Cambridge university press.

Yuan, R. and Burns, A. (2017). Teacher Identity Development through Action Research: A Chinese Experience. Teachers and Teaching, 23(6), 729-749.

Zand-Moghadam, A., and Meihami, H. (2016). TEFL teachers' and non-TEFL teachers' Perceptions on the Relationship between SLA Research and Language Pedagogy. Journal of Language and Cultural Education, 4(3), 233-256.

\section{I identitetą orientuotos anglų kalbos mokytojo rengimo programos kaip glokalaus anglų kalbos mokytojo tapsmo arena}

Hussein Meihami

Širazo universitetas (pašto dėžutė 71964-84334) Eram aikštė, Širazas, Iranas, hussein.meihami@yahoo.com

\section{Santrauka}

Vietinio ir globaliojo švietimo pasikeitimas ị glokalųji švietimą jaučiamas ir anglų kalbos pedagogikoje. Toks pokytis paskatino naują anglų kalbos mokymo ir mokymosi diskursą, kuriuo tikimasi pakeisti anglų kalbos mokytojų rengimo programas. Taigi, šio tyrimo tikslas yra ištirti ị identitetą orientuotų anglų kalbos mokytojų rengimo programų galimybes, plètojant glokalų anglų kalbos mokytojų identitetą, nagrinejjant anglų kalbos, kaip užsienio kalbos, mokytojų perspektyvas. Pagrindinems interviu temoms buvo naudojamas Strausso ir Corbino (1998) pasiūlytas sisteminis požiūris. Interviu gauti duomenys buvo apdorojami remiantis trimis kodavimo lygiais: atviruoju kodavimu, ašiniu kodavimu ir atrankiniu kodavimu. Po diskusijų 
apie anglų kalbos mokymo ir mokymosi būklę, analizuojant interviu rezultatus, buvo nustatyti pagrindiniai ị identitetą orientuotos anglų kalbos mokytojų rengimo programos aspektai, siekiant plètoti anglų kalbos mokytojo glokalų identitetą. Šie aspektai yra susiję su reflektyviąja pedagogika, mažinant atotrūkị tarp teorijos ir praktikos, ịtraukiant anglų kalbos mokytojus i veiklos tyrimus ir ugdant anglų kalbos mokytojų kritinio mąstymo ịgūdžius mokytojų rengimo programose. Taigi, politikos formuotojai kalbų mokytojų rengimo srityje turi atsižvelgti $\mathfrak{i}$ šiuos aspektus, rengdami būsimas mokytojų rengimo programas, skirtas ugdyti anglų kalbos mokytojus, kurie būtų kompetentingi mokyti pagal glokalius poreikius.

Esminiai žodžiai: glokalus švietimas, orientuotas $\mathfrak{i}$ identiteta, veiklos tyrimas, reflektyvioji praktika.

Gauta 20190801 / Received 01082019

Priimta 20191014 / Accepted 14102019 